\title{
THE POWER OF COURTS OVER THE INTERNAL AFFAIRS OF RELIGIOUS GROUPS
}

The power of courts over the internal affairs of churches is, in general, an aspect of the law pertaining to all private associations. However, special problems arising from the concept of separation of Church and State have been held to impose specific limitations upon the courts in this area.

This comment attempts to ascertain the scope of these limitations as acknowledged in judicial practice.

\section{IIMITATIONS ON THE JUDICIAL REVIEW OF CHURCH ACTION}

\section{The Rule-Making Autonomy of Churches}

Courts have frequently stated that the separation of Church and State in the Umited States and the guarantee of religious liberty under our Constitution restrict their power to interfere in the internal affairs of religious associations. ${ }^{1}$ Whatever the proper operation of this restriction, such statements acknowledge that, where churches are concerned, the courts are dealing with orgamisms having special constitutional status.

The rule that churches possess, within their proper ecclesiastical jurisdiction, autonomous powers to provide for their internal law and government was forcefully expounded by the United States Supreme Court in Watson v. Jones. ${ }^{2}$ Freedom to choose a form of government consistent with the dogmas of the particular denomination seems clearly part of the constitutionally guaranteed freedom of worship. Rarely has this been doubted as a general proposition of law..$^{3}$ But courts have sometimes limited the extent to which a church can dictate its members' views on social or political problems of the day. More inportant, courts have at times imposed

1 See Hundley v. Collins, 131 Ala. 234, 243-245, 32 So. 575, 578 (1902) ; Shannon v. Frost, 3 B. Monroe 253, 259 (Ky. 1842); Clapp v. Krug, 232 Ky. 303, 304-305, 22 S.W.2d 1025, 1026 (1929); The State v. Hebrew Congregation 'Dispersed of Judah,' 31 La. Ann. 205, 206-207 (1879); Dees v. Moss Point Baptist Church, 17 So. 1, 2 (Miss. 1895); Pounder v. Ashe, 44 Neb. 672, 679-681, 63 N.W. 48, 50 (1895) ; Morris Street Baptist Church v. Dart, 67 S.C. 338, 341342, 45 S.E. 753, 754 (1903) ; Minton v. Leavell, 297 S.W. 615, 621-622 (Texas Civ. App. 1927).

213 Wall. 679, 728-729 (U.S. 1871): "In this country the full and free right to entertain any religious belief, to practice any rehgious principle, and to teach any religious doctrine which does not violate the laws of morality or property, and which does not infringe personal rights, is conceded to all. The law knows no heresy, and is committed to the support of no dogma, the establishment of no sect. The right to organize voluntary religious associations to assist in the expression and dissemination of any religious doctrine, and to create tribunals for the decision of controverted questions of faith within the association, and for the ecclesiastical government of all the individual members, congregations, and officers within the general association, is unquestioned."

3 But see Bunnell v. Creacy, 266 S.W.2d 98, 100 (Ky. 1954) (if a church were allowed to be governed by a self-perpetuating council of elders under divine authority, this "would be to leave the control of the property of the church in the hands of men whose authority comes from no source recognizable in the law.").

4 See Watson v. Garvin, 54 Mo. 353, 378-381 (1873), doubting that the Presbyterian Cluurch can demand members' adherence to anti-slavery policy of federal government. Contra: Sapp v. Callaway, $208 \mathrm{Ga} .805$, 69 S.E.2d 734 (1952) (error to charge jury that church cannot declare memhership in labor union incompatible with membership in church). 
their own notions of "due process" or "natural law" on religious groups in cases involving proceedings against members leading to disciplimary action or expulsion. ${ }^{5}$ The contrary rule, more compatible with the autonomy accorded religious associations, was set forth by Roscoe Pound in Bonacum v. Harrington ${ }^{6}$ where he said: ${ }^{7}$

However much we may think that open and public proceedings and hearings upon due notice ought to be had in every investigation of every sort of charge or issue, we must remember that it is not our province to impose our views as to such matters upon religious denominations.

Under this rule, religious groups can set their internal order and government in any lawful manner, democratically or tyrannically, and may impose upon their members such conditions of membership as they may see fit. ${ }^{8}$ The church is to be the judge of the requisites of proper internal government and the maintenance of faith and discipline among its members.

This complete internal autonomy distinguishes churches, in the eyes of the law, froin other private associations whose powers in this respect are often curtailed by courts. ${ }^{9}$ There is some suggestion that this differentiation is explained on the theory that courts, before they intervene and impose standards, weigh the social and economic pressures on the individual "to join" or "to belong" to a given group to ascertain the necessity of judicial interposition. ${ }^{10}$ This would hardly justify the rule set out as applying to

5 See Holmes, J., in Gray v. Christian Society, 137 Mass. 329, 331 (1884) (that this no longer seems to be the law in Massachusetts, see note 49 infra) ; Powanda v. Pido, $304 \mathrm{~Pa} .42$, 155 Atl. 90 (1931) ; Carter, J., dissenting in Erickson v. Gospel Foundation of Calif., 43 A.C. 593, 601-604, 275 P.2d 474, 481-482 (1954).

665 Neb. 831, 91 N.W. 886 (1902).

7 Id. at 837,91 N.W. at 888 ; see Dittemore v. Dickey, 249 Mass. 95, 110, 144 N.E. 57,63 (1924); Morris Street Baptist Church v. Dart, 67 S.C. 338, 344, 45 S.E. 753, 755 (1903); see Chafee, The Internal Afjairs of Associations Not for Profit, 43 HARv. L. REv. 993, 1018 (1930).

8 This freedom is limited by the permissible exercise of the government's pohice power and may not imperil the morals, health and safety of the community. Davis v. Beason, 133 U.S. 333 (1890) ; Reynolds v. U.S., 98 U.S. 145 (1879).

${ }^{9}$ Dawkins v. Antrobus, 17 Ch.D. 615 (1879) (club rules must conform to natural justice); Osborne v. Amalgamated Society of Railway Servants, [1909] $1 \mathrm{Ch}$. 163 (invahidating provisions of union by-law that members must contribute to labor party campaign fund); Williams v. International Brotherhood of Boilermakers, 27 Cal.2d 586, 165 P.2d 903 (1946) (outlawing racial discrimination by labor umion); James v. Marinship Corp., 25 Cal.2d 721, 155 P.2d 329 (1944) (umion given choice of abandoning closed shop or admitting, Negroes to membership); Betts v. Easley, 161 Kan. 459, 169 P.2d 831 (1946) (outlawing racial discrimination in labor union); Cameron v. International Union, 118 N.J. Eq. 11, 176 Atl. 692 (1935) (striking down discriminatory scbeme in umion constitution maintaining a small group of old members in permanent control) ; Matter of Gallaher v. American Legion, 154 Misc. 281, 277 N.Y.S. 81 (1934) (striking down provision in Legion constitution forbidding local posts to take positions on public issues contrary to stand of national commander).

10 Compare the "alternative of withdrawal" arguments in St. Benedict Order v. Steinlauser, 234 U.S. 640, 649 (1914) ("The validity of agreements providing for community ownership with renunciation of individual rights of property during the continuance of membership in the commumity, where there is freedom to withdraw, has repeatedly been affirmed.") with Harris v. Geier, 112 N.J. Eq. 99, 106, 164 Atl. 50, 53 (1932) ("A member of a [labor] union can resign-and starve."). 
all religious organizations, ${ }^{11}$ and the better explanation is found in the ideas underlying our constitutional scheme of religious freedom. In the realm of the spiritual the individual is left as the final arbiter of any personal conflicts of loyalty which may arise.

Conceding religious associations the right to make their own law and internal order of government, it does not follow that by denial of judicial relief the church should also be conceded the right to violate its own selfimposed law. This is the probleni to be examined next.

\section{The Rule of Conclusiveness of Decisions of Church Tribunals}

In Watson v. Jones ${ }^{12}$ the majority of a local parish of the Presbyterian Churcl had, in effect, been declared to be schismatic by the highest judicatory of the churcl. The Supreme Court, in disposing of the conflicting claims to the parish property, ruled that it was bound by this ecclesiastical decision ${ }^{13}$ and awarded the property to those remaining faithful to the official hierarchy of the churcli. The language employed by the Watson case, ${ }^{14}$ whether or not so intended, has lent itself readily to the formulation of a rule of general applicability whereby courts are denied any power to review, for substantial compliance with the law of the church, the decision-making processes of church tribunals.

The reasons supplied by the Court for this rule were that membership in a church involves a submission to the law and jurisdiction of the church which precludes appeal to secular courts in ecclesiastical matters, ${ }^{15}$ and that courts are not well equipped to adjudicate difficult questions of ecclesiastical law. ${ }^{16}$ The former argument hardly seems sound since submission to the law of the church does not necessarily include submission to the violation by the church of its own law. Nor would court review negate the rule-making autononyy of churches, since it is the church's own law which

11 See the allegations of the complaint in Kauffman v. Plank, 214 Ill.App. 306, 309-310 (1919) as to the effects of an expulsion from the Mennomite Church in an Amish community.

1213 Wall. 679 (U.S. 1871).

13 Id. at 727: "In this class of cases we think the rule . . . is, that, whenever the questions of discipline, or of faith, or ecclesiastical rule, custom, or law have been decided by the highest of these church judicatories to which the matter has been carried, the legal tribunals must accept such decisions as final, and as binding on them, in their application to the case before tbem."

14 Id. at 733-734: "But it is a very different thing where a subject-matter of dispute, strictly and purely ecclesiastical in its character, - a matter over which the civil courts exercise no jurisdiction, - a matter which concerns theological controversy, church discipline, ecclesiastical government, or the conformity of the members of the church to the standard of morals required of them,-becomes the subject of its action .... [I]t is easy to see that if the civil courts are to inquire into all these matters, the whole subject of doctrinal theology, the usages and customs, the written laws, and fundamental organization of every religious denomination may, and must, he examined into with minuteness and care, for they would become, in almost every case, the criteria by which the validity of the ecclesiastical decree would be determined in the civil court. This principle would deprive these bodies of the riglt of construing their own church laws, would open the way to all the evils which we have depicted ... and would, in effect, transfer to the civil courts where property rights are concerned the decisions of all ecclesiastical questions."

15 Id. at 729.

16 Ibid. 
is thereby vindicated and given effect. ${ }^{17}$ The second reason given is also fallacious, for the difficulty of a legal question is not a valid ground for denying judicial relief otherwise warranted. ${ }^{18}$

Subsequent decisions of the Supreme Court have added various qualifications to the rule of conclusiveness. It has been held that courts, when ruling on the effect of disciplinary church action on property rights, must ascertain whether the body which acted was, in fact, the church and not a usurper..$^{10}$ In a more recent case it was indicated that the court could review the action of ecclesiastical authorities for fraud, collusion and arbitrariness. ${ }^{20}$

Kedroff v. St. Nicholas Cathedral ${ }^{21}$ contaims the latest pronouncements of the Umited States Supreme Court on this point. The Court gave praise to the spirit of Watson $v$. Jones ${ }^{22}$ and perhaps elevated the Watson rule to the dignity of a constitutional requirement. ${ }^{23}$ Yet the facts in the Kedroff case merely called for a ruling on a dispute between the Russian Orthodox Church in North America and the Russian Orthodox Patriarchate in Moscow over the power to appoint bishops for the North American Church. ${ }^{24}$ The court held simply that certain arrangements made between the two bodies did not give the North American Church the power it claimed; and that a New York statute ${ }^{25}$ which sought to vest control of the church property im the appointee of the North American Church was unconstitutional. There was no direct challenge of the Patriarchate's general position as head of the church nor of the procedure employed in appointing the bishop. ${ }^{28}$ In referring to the freedom of the church to appoint its own clergy, the Court stated that such right is constitutionally protected "where no improper methods of choice are proven." 27

In the following discussion of the two main types of litigation involving churches, cases involving disciplinary church action against members and

17 For a critique of the Watson rule see Zolmanann, American CHuRcr Law 287-293 (1933).

18 "The civil courts are presumed to know all the law touching property rights; and if questions of ecclesiastical law, connected with property rights, come before them, they are compelled to decide them. They have no power to abdicate their own jurisdiction and transfer it to other tribunals. If they are not sufficiently advised concerning the questions that arise, it is their duty to make themselves acquainted with them, in all their bearings, and not to blindly register the decrees of tribunals having no jurisdiction whatever over property." Wat- . son v. Garvin, 54 Mo. 353,377 (1873).

19 Bouldin v. Alexander, 15 Wall. 131 (U.S. 1872). The court denied, however, that the question of membership is generally open to court review. Id. at 139-140.

20 See Brandeis, J., in Gonzales v. Archbishop, 280 U.S. 1, 16 (1929).

21344 U.S. 94 (1952).

$23 I d$. at 116.

23 The Supreme Court, 1952 Term, 67 HARV. L. Rev. 91, 110 (1953).

24 See 3 Stokes, Church and State in rexe United States, 529-535 (1950); Pfrefer, Church, State and Freedoar, 248-251 (1953).

25 Religious Corporation Law. Art. 5 C; McKinney's N.Y. Laws $§ 107$.

20 See 344 U.S. 94, 106 (1952); The Supreme Court, 1952 Term, 67 HaRv. L. REv. 91,112 (1953).

27344 U.S. 94, 116 (1952), citing the dictum in Gonzales v. Archbishop, 280 U.S. 1, 16 (1929), and Taft, J., in Brundage v. Deardorf, 55 Fed. 839, 847 (C.C. N.D. Ohio 1893) for this reservation. 
cases involving disputes over property rights following a schism or division in a church, the impact of the Watson case will be examined.

\section{THE PROTECTION OF MEMBERSHIP}

As a general rule, a person aggrieved by the wrongful exercise of the church's disciplinary powers must, before seeking relief in the courts, first exhaust the possibilities of appeal within the church. ${ }^{28}$ Where internal remedies have been pursued to no avail, the expelled member, in turming to the court of equity, faces the rule that equity will protect only property rights. ${ }^{20}$ And the prevailing view in this country is that church membership is not an interest in property..$^{30}$

It has been argued that court jurisdiction must attach in wrongful expulsion cases on the theory that the laws of the church form a contract binding on and enforceable by each member. ${ }^{31}$ Sometimes courts have also gone far to find some incidental property interest connected with membership. ${ }^{32}$ Both theories of recovery have been criticized as fictitious. ${ }^{33}$ Property interests connected with membership are at best incidental and it is the emotional and spiritual content which makes it a valuable right. ${ }^{34}$ The merits of the contract theory are outweighed by the fact that it may lead to liability of individual members to the person wrongfully expelled and might also give courts the right to imterpret for themselves the canons of a church. ${ }^{35}$ That the theory is founded on fiction is obvious: often there is no formal introduction into membership, and in many churches membership may be obtained by baptism in infancy. No assumption of contractual obligations could be inferred from either. ${ }^{3 a}$

A more realistic rule is to recognize membership in religious associations as a personal right entitled to equitable protection. This accords with

28 Knauss v. Adventist Ass'n, 117 Colo. 540, 190 P.2d 590 (1948); German Reformed Church v. Seibert, 3 Barr. 282 ( $\mathrm{Pa}$. 1846). This rule applies to all private associations. Dragwa v. Federal Labor Union, 136 N.J. Eq. 172, 41 A.2d 32 (1945).

29 For the history of the rule see Pound, Equitable Relief against Defamation and Injuries to Personality, 29 Harv. L. REv. 640, 642 et seq. (1916).

30 Hundley v. Collins, 131 Ala. 234, 32 So. 575 (1902); State, ex rel., v. Cummins, 171 Ind. 112, 85 N.E. 359 (1908); Cooper v. Bell, 269 Ky. 63, 106 S.W.2d 124 (1937); Clapp v. Krug, 232 Ky. 303, 22 S.W.2d 1025 (1929); Jenkins v. New Shiloh Baptist Ch., 189 Md. 512, 56 A.2d 788 (1940) ; Dees v. Moss Point Baptist Church, 17 So. 1 (Miss. 1895). See Zorrmanns, AmarrICAN CHURCH LAW, 306-307 (1933).

31 Slaughter v. New St. John Miss'y Bap. Church, 8 La. App. 430 (1928); see Rosicrucian Fellow. v. Rosicrucian Etc. Ch., 39 Cal.2d 121, 131-132, 245 P.2d 481, 488 (1952) ; Thoinas v. Lewis, 224 Ky. 307, 311, 6 S.W.2d 255, 257 (1928); Bear v. Heasley, 98 Mich. 279, 30\%, 57 N.W. 270, 280 (1893). This is the theory urged by ZolnmaNn, supra note 30 at 312-313. But see Nance v. Busby, 91 Tenn. 303, 325-327, 18 S.W. 874, 879 (1892).

32 See ZorcimanN; supra note 31, at 306.

33 Chafee, The Internat Affairs of Associations Not for Profit, 43 Hanv. I. Ruv. 993, 998, 1002-1003 (1930).

34 Id. at 998: "Excommunication from a church means loss of the opportunity to worship God in familiar surroundings with a cherished ritual, and inflicts upon the devout believer loneliness of spirit and perhaps the dread of eternal damnation. In coinparison with such einotional deprivations, mere losses of property often appear trivial."

35 Id. at 1001-1007.

36 See Note, 13 Cornent L. Rev. 464, 466 (1928). 
a substantial trend toward equitable protection of membership in a wide variety of groups and similar rights. ${ }^{37}$

The language of Watson $v$. Jones ${ }^{38}$ sets up an additional constitutional barrier to court review of disciphinary action for violation of internal church law. Difficulty in evaluating the case law here arises from confusion by many courts of Watson language with the rule that equity will protect only property rights. Kentucky decisions may serve as an illustration. The case of Shannon v. Frost ${ }^{39}$ was relied on in Watson and has served as precedent for decisions in many jurisdictions. The Shannon opinion contains the most vigorous constitutional arguments against court interference of any kind..$^{40}$ While this case is still regarded as stating the law in Kentucky, ${ }^{41}$ it was later held that the court could review the expulsion of a church secretary because of his pecuniary interest in menubership. ${ }^{42}$ Relief was denied in the same action to other expelled members who were without remunerative office in the church.

Thus it seems that courts have talked in terms of constitutional prohibition of intervention while, $m$ fact, applying the rule that equity protects only property rights. Today, equitable jurisdiction is extended to other rights or the courts go far to find some "property interest" warranting intervention under traditional equity rules. The use by nuany courts of constitutional arguments when denying rehef, in cases where the asserted right was simply one not recognized in law, has hidden the real legal issue.

Today it appears that courts of many jurisdictions will review the internal proceedings of religious societies to some extent. These jurisdictions include California, ${ }^{43}$ Colorado, ${ }^{44}$ Delaware, ${ }^{45}$ Florida, ${ }^{46}$ Iowa, ${ }^{47}$ Ken-

37 See authorities discussed in Berrien v. Pollitzer, 165 F.2d 21 (App. D.C. 1947) and Randolpl v. First Baptist Clurch, 120 N.E.2d 485 (Ohio Com. Pl. 1954). See also Orloff v. Los Angeles Turf Club, 30 Cal.2d 110, 116-118, 180 P.2d 321, 324-325 (1947).

38 See note 14 supra.

393 B. Munroe 253 (Ky. 1842).

40 Id. at 258-259: "We cannot decide who ought to be members of the church, nor whether the excommunicated have been justly or unjustly, regularly or irregularly cut off from the body of the church. We must take the fact of expulsion as conclusive proof that the persons expelled are not now members of the repudiating church; for, whether right or wrong, the act of excommunication inust, as to the fact of membership, be law to this Court .... The judicial eye of the civil authority of this land of religious liberty, cannot penetrate the veil of the Church, nor can the arm of this Court either rend or touch that veil for the forbidden purpose of vindicating the alleged wrongs of the excinded members."

41 See Cooper v. Bell, 269 Ky. 63, 106 S.W.2d 124 (1937) ; Thomas v. Lewis, 224 Ky. 307, 6 S.W.2d 255 (1928).

42 Clapp v. Krug, 232 Ky. 303, 22 S.W.2d 1025 (1929).

43 See text at notes 68 et seq. infra.

44 See Knauss v. Adventist Ass'n, 117 Colo. 540, 542, 190 P.2d 590, 591 (1948).

15 Trustees U.A.M.E. Church v. Ennis, 27 Del. Ch. 1, 29 A.2d 374 (1942).

40 See Epperson v. Myers, 58 So.2d 150, 152 (Fla. 1952) and First Free Will Ch. of Blountstown, Inc. v. Franklin, 148 Fla. 277, 285, 4 So.2d 390, 393 (1941) (review restricted to fraud, collusion or arbitrariness).

47 Ragsdale v. Church of Christ, 244 Iowa 474, 55 N.W.2d 539 (1953). 
tucky, ${ }^{48}$ Massachusetts, ${ }^{48}$ Missouri, ${ }^{50}$ New Jersey, ${ }^{51}$ Ohio, ${ }^{62}$ Pennsylvania, ${ }^{63}$ South Carolina, ${ }^{54}$ Texas, ${ }^{55}$ Washington ${ }^{56}$ and the District of Columbia. ${ }^{57}$ A clearly contrary view prevails in Georgia, ${ }^{58}$ Illinois, ${ }^{50}$ Indiana, ${ }^{60}$ Maryland, ${ }^{61}$ Mississippi $^{62}{ }^{20}$ Nebraska $^{63}$ and Tennessee. ${ }^{64}$

Some other jurisdictions cannot be classified with certainty. The Alabama cases have denied review of expulsion from membership but there is dictum that the rule may be otherwise $m$ case of expulsion of a pastor. ${ }^{\text {or }}$ In Louisiana ${ }^{66}$ and New York ${ }^{67}$ the decisions vary in their approach and seem irreconcilable.

48 Clapp v. Krug, 232 Ky. 303, 22 S.W.2d 1025 (1929); see text at note 42 supro.

49 Moustakis v. Hellenic Orthodox Society, 261 Mass. 462, 159 N.E. 453 (1928); Gray v. Christian Society, 137 Mass. 329 (1884) (reviewing expulsion and ruling that by-laws must provide for notice and hearing). Cf. Dittennore v. Dickey, 249 Mass. 95, 108-112, 144 N.E. 57, 62-63 (1924) (apparently abandoning the "due process" requirement).

50 Longmeyer v. Payne, 205 S.W.2d 263 (Mo.App. 1947); Briscoe v. Williams, 192 S.W.2d 643 (Mo. App. 1946). Contra, State ex rel. Hynes v. Catholic Church, 183 Mo. App. 190, 170 S.W. 396 (1914). See Murr v. Maxwell, 232 S.W.2d 219, 234-237 (Mo. App. 1950).

51 Harrison v. Floyd, 26 N.J. Super. 333, 97 A.2d 761 (1953).

52 Randolph v. First Baptist Church, 120 N.E.2d 485 (Ohio Coin. P1. 1954).

53 Kaminski v. Hoynak, 373 Pa. 194, 95 A.2d 548 (1953).

54 See Turbeville v. Morris, 203 S.C. 287, 306, 26 S.E.2d 821, 828 (1943). But see Church v. Dart, 67 S.C. $338,342-343,45$ S.E. 753,754 (1903).

55 David v. Carter, 222 S.W.2d 900 (Texas Civ. App. 1949)

56 Hendryx v. People's United Church, 42 Wasb. 336, 84 Pac. 1123 (1906) (expulsion voided for fraud).

57 Taylor v. Jackson, 273 Fed. 345 (App. D.C. 1921). But cf. U.S. ex rel. Johnson v. First Colored Baptist Church, 13 F.2d 296 (App. D.C. 1926) (denying relief, but facts show no allegation of violation of church law). Both cases are cited as precedent in Berrien v. Pollitzer, 165 F.2d 21, 23 (App. D.C. 1947) (granting relief to meinber wrongfully expelled from secular voluntary association).

58 Stewart v. Jarriel, 206 Ga. 855, 59 S.E.2d 368 (1950); Sapp v. Callaway, 208 Ga. 805, 69 S.E.2d 734 (1952) (alternative lolding). But of. Everett v. Jennings, 137 Ga. 253, 73 S.E. 375 (1911) (court syllabus no. 4).

50 Kauffman v. Plank, 214 IIl.App. 290 (1919) and 214 Ill.App. 306 (1919).

60 State ex rel. Hatfield v. Cunumins, 171 Ind. 112, 85 N.E. 359 (1908); see Kompier v. Thegza, 213 Ind. 542, 548, 13 N.E.2d 229, 232 (1938).

61 Jenkins v. New Shiloh Baptist Ch., 189 Md. 512, 56 A.2d 788 (1948). But see Evans v. Shiloh Baptist Church, 196 Md. 543, 550-551, 77 A.2d 160, 163-164 (1950) (reserving question of review in case of remunerative church office).

62 Dees v. Moss Point Baptist Church, 17 So. 1 (Miss. 1895).

63 Deloisted v. Hilson, 120 Neb. 788, 235 N.W. 340 (1931) ; Bonacum v. Murphy, 71 Néb. 487,104 N.W. 180 (1905), vacating on reliearing Bonacum v. Murphy, 71 Neb. 463, 98 N.W. 1030 (1904).

64 Nance v. Busby, 91 Tenn. 303, 18 S.W. 874 (1892) ; see Mason v. Winstead, 265 S.W.2d 561 (Tenn. 1954).

05 Mount Olive Primitive Baptist Church v. Patrick, 252 Ala. 672, 42 So.2d 617 (1949) (denying power to review) ; Hundley v. Collins, 131 Ala. 234, 32 So. 575 (1902). But see Barton v. Fitzpatrick, 187 Ala. 273, 280, 65 So. 390, 393 (1914), quoted with approval in Highland View Baptist Church v. Walker, 259 Ala. 301, 304-305, 66 So.2d 122, 125 (1953) (dictum that rule as to salaried pastor may be different).

66 State v. Hebrew Congregation "Dispersed of Judah," $31 \mathrm{La}$. Ann. 205 (1879) and State v. Tulane Ave. Baptist Church, 144 So. 639 (La.App. 1932) (denying power to review). Contra: Slaugliter v. New St. John Miss'y Bap. Cliurch, 8 La.App. 430 (1928).

67 Baxter v. McDonnell, 155 N.Y. 83, 49 N.E. 667 (1898) (denying review of removal of minister) ; Connitt v. RP.D.C. of N. Prospect, 54 N.Y. 551 (1874). But cf. Matter of Koch, 257 N.Y. 318,178 N.C. 545 (1931) (reviewing proceeding leading to plaintiff's removal from board of directors of Christian Science Church; relief denied because plaintiff waived defects 
The law in California warrants special discussion. Whether a person, expelled from membership in violation of church law, can obtain reinstatement is unsettled. In Providence Baptist Church v. Superior Court ${ }^{68}$ the California Supreme Court held proper the review, for compliance with church law, of the removal of a pastor by a congregationally governed churcl and the ordering of a new election; the emoluments of the pastoral office were held a sufficient property interest for equitable intervention. ${ }^{69}$ The court made an apparently unsound distinction of an earlier District Court of Appeal decision ${ }^{70}$ which had invoked Watson in loolding that a court cannot review the attempted ouster of a pastor, even though the complaint alleged that the vote of the membership had been suppressed by fraud of the moderator. ${ }^{71}$

The court intimated further a distinction between congregationally governed churches, where memberslip meetings are the highest governing body, and hierarchical or associational churches, which provide special judicatories to deal with matters of church discipline. The court implied that review would be proper in the former case only. ${ }^{72}$ Such distinction seems unwarranted since court review must, in any event, be restricted to whether or not there was substantial compliance with church law. To discriminate between different churches on the basis of their internal organization hardly seems sound.

Removal of a person from membership in a church corporation, as distinguislied from membership in the general churcli body, has been lield to be interference with a right sufficient to warrant court intervention, even where the by-laws permit only members of the general church to be members of the corporation. ${ }^{73}$ Empliasis was given to the "property interest" connected with corporation membership. ${ }^{74}$

of church trial; Lehman and Pound dissenting that defects could not be waived). See Rector, Etc., of Church of Holy Trinity v. Melish, 194 Misc. 1006, 88 N.Y.S.2d 764 (1949), aff'd, 276 App.Div. 1088, 96 N.Y.S.2d 496 (1950), aff'd, 301 N.Y. 679, 95 N.E.2d 43 (1950), cert. denied, 340 U.S. 936 (1951) (reaffirming rule of Connitt case, supra, but no violation of church law shown); for an account of the Melish case, see 3 Stokes, ChuRCen AND STATE IN THE UNITED States, 395-403 (1950) and Pfeffer, Church, State and Freedom, 251-256 (1953).

6340 Cal.2d 55, 251 P.2d 10 (1952).

69 Id. at $61,62,251$ P.2d at $13,14$.

70 Maxwell v. Brougher, 99 Cal.App.2d 824, 222 P.2d 910 (1950). "[T]he court [in Maxwell v. Brougher] was considering the jurisdiction of the court to determine the manner in which the members and officers were to proceed in hearing and disposing of charges against the pastor. Jurisdiction was denied but on the ground that the decision of the church tribunal on ecclesiastical matters is final rather than whether the church had followed its rules. No consideration was given to the emoluments of the position." Providence Baptist Church v. Superior Ct., 40 Cal.2d 55, 62-63, 251 P.2d 10, 14 (1950).

71 In Maxwell v. Brougher, note 70 supra, the District Court of Appeal also relied on the fact that in a Baptist Church the majority must prevail; and this in the face of the allegations of the complaint that the actual majority vote was suppressed by fraud.

72 Providence Baptist Church v. Superior Ct., 40 Cal.2d 55, 61, 251 P.2d 10, 14 (1952).

73 Burnett v. Banks, 130 A.C.A. 750, 279 P.2d 579 (1955).

74 Ibid. The court failed to elaborate on the nature of the "property interest." But cf. Erickson v. Gospel Foundation of Calif., 43 A.C. 593, 275 P.2d 474 (1954), where the court not only casts doubt on the rule of court review, but also demies that membership on the board of directors of a religious foundation is a "property interest." Id. at 598, 275 P.2d at 477. 
Thus there is California authority for review of the removal of a pastor or one who has a property interest in his membership. Beyond this, there is dictum in a District Court of Appeal opinion that disciplinary actions taken against a member will be reviewed for violation of church law. ${ }^{75}$ Since California equity protects personal as well as property rights, ${ }^{70}$ it is to be hoped that a wrongfully expelled church member may find relief in California courts.

In surveying the case law on equitable protection of membership in religious groups or pastoral office, it is fair to say that a majority of courts will review, in varying degrees, church proceedings for compliance with church law. The question is one of defining riglits for whose protection the courts will undertake this review. Where a minister or the holder of a remunerative ecclesiastical office shows removal in violation of church law, most courts will grant relief. In cases of wrongful expulsion from membership, the outcome depends not only on whether the courts will review ecclesiastical decisions at all but also on whether membership is accorded equitable protection in the particular jurisdiction. The fact that courts have strained the traditional concept of "property right" to cover such cases shows that they are willing to intervene to prevent injustice. The current trend in American jurisdictions in favor of extension of equitable protection to personal rights will serve to clarify the issue.

\section{DISPUTES OVER CHURCH PROPERTY FOLLOWING SCHISM OR DIVISION IN A CHURCH}

That courts must, of necessity, intervene and decide the most complicated questions of church government, law and doctrine is slown by those cases where a schism or division has occurred in a church, and the court is asked to settle the claims of the contending factions to the church's property.

Under the rule of Watson $v$. Jones: ${ }^{77}$

(1) If the property subject to the controversy is impressed with an express trust for the benefit of a particular doctrine, purpose or body, the terms of the trust will be enforced even to the exclusion of the majority of a parish, or the government of a church, who desire to abandon or deviate froin the original dogma or purpose.

(2) If a churcli is independently organized and congregationally governed and its property not impressed with an express trust providing otherwise, those who constitute the majority of the parish, or those who adhere to the government of the parish regularly constituted, are entitled to the property.

75 See Linke v. Church of Jesus Christ, 71 Cal.App.2d 667, 668-669, 163 P.2d 44, 45 (1945). This dictum was relied on in David v. Carter, 222 S.W.2d 900, at 905 (Texas Civ. App. 1949) for granting relief to wrongfully expelled nember.

${ }^{76}$ See Orloff v. Los Angeles Turf Club, 30 Cal.2d 110, 116-118, 180 P.2d 321, 324-325 (1947) and authorities cited.

7713 Wall. 679, 722-727 (U.S. 1871). 
(3) If a local parish holds property not impressed with an express trust and is itself part of a nation-wide structure, with supreme judicatories to adjudge such controversies, that faction of the local church which is recognized by and adheres to the nation-wide church is entitled to the property. This last situation obtained in fact in Watson $v$. Jones.

The rule of looking to the properly constituted church government is recognized as a general principle in every court. It has been deduced that congregationally governed churches, which are by the nature of their governmental structure independent and normally governed by parish-majority rule, ${ }^{78}$ can freely join and withdraw from arrangements of cooperation with other independent local churches of their denomination. ${ }^{79}$ In associational churches, where local parishes are part of the nation-wide church structure $^{80}$ no local parish can declare itself independent or join another denominational hierarchy. ${ }^{81}$

But in a number of jurisdictions, exceptions from the two last mentioned rules of the Watson case have been recognized because their hiteral application would allow the governing majority in a congregationally governed church, or the official hierarchy in an associational churcli, to devote the property not impressed with an express trust to purposes alien to the church, such as doctrines radically different from those hitherto followed. The government of the church would prevail over the resistance of substantial minorities among the membership, or even over the majority of members where majority rule has no place in a particular church's government. These exceptions from the Watson rule are based on the theory that church property, absent an express trust, is held in implied trust for the benefit of those worshipping in the particular manner demanded by the faith at the time of the acquisition of the property. ${ }^{82}$ The trust is enforce-

78 See Barton v. Fitzpatrick, 187 Ala. 273, 278, 65 So. 390, 392 (1914).

79 Ables v. Garner, 220 Ark. 211, 246 S.W.2d 732 (1952); Keith v. First Baptist Church, 243 Iowa 616, 50 N.W.2d 803 (1952); Ragsdale v. Church of Christ, 244 Iowa 474, 55 N.W.2d 539 (1952); Martin v. Ky. Christian Conference Inc., $255 \mathrm{Ky} .322,73$ S.W.2d 849 (1934). Cf. discussion of variations among different Baptist denominations in Trett v. Lambeth, 195 S.W.2d 524, 533-534 (Mo.App. 1946).

80 See the discussion of different church governments in XIII ENCYCLOPEDIA OF TEE SOCIAL SCIENCEs 246 et seq. (1934).

81 First English E. L. Church v. Dysinger, 120 Cal.App. 139, 6 P.2d 522 (1932); McAuliffe v. Russian Greek Cathohc Church, 130 Conn. 521, 36 A.2d 53 (1944); Borgman v. Bultema, 213 Mich. 684, 182 N.W. 91 (1921); Methodist Church v. Church, 98 N.H. 498, 104 A.2d 204 (1954) ; First Church of the Brethren v. Snider, 367 Pa. 78, 79 A.2d 422 (1951).

82 Stallings v. Finney, 287 III. 145, 122 N.E. 369 (1919); Church of God, Decatur, IIl., v. Finney, 344 MIl.App. 598, 101 N.E.2d 856 (1951); Whipple v. Fehsenfeld, 173 Kan. 427, 249 P.2d 638 (1952) ; Parker v. Harper, 295 Ky. 686, 175 S.W.2d 361 (1943). See Highland View Baptist Church v. Walker, 259 Ala. 301, 305, 66 So.2d 122, 125-126 (1953) ; Caples v. Nazareth Church of Hopewell Ass'n, 245 Ala. 656, 659, 18 So.2d 383, 385 (1944); Ables v. Garner, 220 Ark. 211, 214-215, 246 S.W.2d 732, 734 (1952); Keith v. First Baptist Church, 243 Iowa 616, 619-620, 50 N.W.2d 803, 805 (1952); Bunnell v. Creacy, 266 S.W.2d 98, 99 (Ky. 1954). See also McAuhffe v. Russian Greek Catholic Church, 130 Conn. 521, 527 and 536, 36 A.2d 53, 55-56 and 59 (1944), which relies on Attorney General v. Pearson, 3 Mer. 353, 36 Eng. Rep. 135 (1817), an authority expressly rejected by Watson v. Jones, 13 Wall. 679, 727 (U.S. 1871) as not applicable in the United States. See Notes, 15 Notre DaMe LAwYER 224 (1940), 39 HARV. L. REv. 1079 (1926). 
able by the faithful minority even against the government of the church, regularly constituted.

The danger of this rule lies in tying the church to the letter of its dogmas, thus hindering its development and adjustment to modern social conditions. This was illustrated by the effects of the decision of the Lords in the Free Church of Scotland Appeal. ${ }^{83}$ In that case the House of Lords awarded the property of the Scottish Church to a small minority of its membership, finding that the majority had abandoned some of the original tenets of faith, thereby forfeiting all rights to the church's property. Of this decision it was said that it tied the church so rigidly to the trust deeds of her foundation as to enslave it to the dead..$^{84}$

American courts have quite generally taken the liberal attitude urged in the dissent of Lord Macnaghten. ${ }^{85}$ In Horsman v. Allen ${ }^{80}$ the California Supreme Court passed on the effects of a revision of the confession of faith in the Church of the Umited Brethren. The constitution of the church forever enjoined changes in the confession of faith. This clause was repealed by the resolution which also adopted the doctrinal change. The court upheld revision and amendment as not constituting too radical a departure from the traditional faith of the church. Similar results obtained in the vast majority of cases dealing with this United Brethren dispute in other jurisdictions. ${ }^{87}$

This liberal approach appears sound because, while in England the decision of the Lords was speedily remedied by an Act of Parliament, ${ }^{88}$ such power is denied American legislatures by the First and Fourteenth Amendments. $^{89}$

Quite generally, American courts have taken an encouraging attitude toward merger movements among churches and have allowed adjustments necessary to such umions against the claims of dissenting minorities, who were often in majority in a given local parish. The California decision in accord with this attitude, Committee of Missions v. Pacific Synod, ${ }^{, 0}$ is typical of decisions throughout the country in the litigation following the merger of the Presbyterian Church and the Cumberland Presbyterian Church, a merger which was resisted in many local Cumberland parishes. ${ }^{01}$

83 Free Church of Scotland (General Assembly of) v. Overtoun (Lord), [1904] A.C. 515; for full report see The Free Church of Scotland Appeal (Orr ed. 1904); for discussion see Laski, The Personality of Associations, 29 Harv. L. REV. 404, 418-419 (1916); FIGGIS, ChurcIIIS nN THE MODERN STATE, 18-23, 32-39 (1913).

84 FIGGIs, supra note 83 , at 39 .

85. "The question, therefore, seems to be this .... Was the Free Church by the very condition of her existence forced to cling to her subordinate standards with so desperate a grip that she has lost hold and touch of the supreme standard of her faith? Was she from birth incapable of all growth and development? Was she (in a word) a dead branch and not a living Church ?" [1904] A.C. 515, 630-631.

86129 Cal. 131, 61 Pac. 796 (1900).

87 Zolimann, American Church Law, 203-206 (1933) and cases cited.

885 EDw. VII, c.12 (1905).

89 Kedroff v. St. Nicholas Cathedral, 344 U.S. 94 (1952).

80157 Cal. 105, 106 Pac. 395 (1909).

91 Zolimani, Amerucan Church Law, 210-218 (1933) and cases cited. 
Of course, even a very liberal approach will not prevent cases coming before courts which force a clioice between the rule wlich makes conclusive the decisions of the churcli government and the theory of an implied trust.

The California courts have refused to recognize implied trusts for the benefit of specific dogmas or tenets of faith and liave declared the decisions of proper ecclesiastical tribunals to be final and conclusive. ${ }^{92}$ Absent an express trust providing otherwise, the property remains with the regularly constituted government of the churcl, so long as the identity of the church is maintained or traceable to a legal successor. Only diversion to an entirely new church organization will be prevented..$^{33}$

It should, however, be noted that, while these principles were clearly set forth by the California Supren1e Court in Committee of Missions $v$. Pacific Synod, ${ }^{94}$ the same court had warned only mine years earlier in Horsman v. Allen ${ }^{95}$ that it would not allow the property to go with the church government in the unlikely case of a total subversion of the basic faith of a church, if faithful members reniain. ${ }^{96}$

As to the conclusiveness of cluurch decisions in litigation over property rights, it was indicated in Wheelock v. First Presb. Church ${ }^{97}$ that the decision of a proper churcl authority in regard to the disposition of clrurch funds is not an ecclesiastical decision and therefore not binding on the civil courts. This distinction, especially in the context of the case, does not seen sound and has not been mentioned in later cases. Ecclesiastical decisions in litigation of this type always affect judicial disposition of property riglits. It is, of course, true that ecclesiastical decisions do not replace court orders and require secular sanction to be given secular effect.

\section{CONCLUSIONS}

In litigation imvolving church membership rights, courts have too often confused constitutional and equitable problems. Recognition of member-

92 Committee of Missions v. Pacific Synod, 157 Cal. 105, 106 Pac. 395 (1909); Baker v. Ducker, 79 Cal. 365, 21 Pac. 764 (1889) ; First English E. L. Church v. Dysinger, 120 Cal.App. 139, 6 P.2d 522 (1932) and 137 Cal.App. 228, 30 P.2d 545 (1934). Cf. Christian Church of Vacaville v. Crystal, 78 Cal.App. 1, 247 Pac. 605 (1926).

93 Dyer v. Superior Court, 94 Cal.App. 260, 271 Pac. 113 (1928) (alternative holding).

04157 Cal. 105, 127-128, 106 Pac. 395, 403 (1909).

95129 Cal. 131, 61 Pac. 796 (1900).

$96 \mathrm{Id}$. at 135, $61 \mathrm{Pac}$. at 798: "[T] he seceding body must, in general, be regarded as abandoning the church; nor is there any exception to this rule unless in the case of usurpation of power in the governing body so revolutionary in its character as to result either in the creation of a new and essentially different organization, or in such radical change of the articles of faith as to constitute an essentially different rehigion from that previously followed by the church." As to the conclusiveness of ecclesiastical decisions, the court adopted the language of Bear $\mathrm{v}$. Heasley, 98 Mich. 279, 290, 57 N.W. 270, 274 (1893) to the effect that, while normally the decisions of church judicatories must be conclusive in ecclesiastical matters, there is an exception "in a case where even in the minds of laymen no doubt can exist, and it is clear, beyond controversy, that the fundamental principles of the church have been destroyed by the one party and been adhered to by the other." 129 Cal. 131, 138, 61 Pac. 796, 799 (1900).

07119 Cal. 477, 51 Pac. 841 (1897) (Synod of Presbyterian Church had ordered partition of parish under its jurisdiction and division of parish funds. The court enforced the division of the funds, but by reason of its own equitable powers rather than because synnd decision was conclusive). 
ship as a valuable right warranting equitable protection is an essential step in arriving at tenable results. While courts should refrain from imposing their own views and standards of due process on religious groups and, in accord with our constitutional scheme, should grant them the widest permissible scope of rule-making autonomy, courts should review disciplinary measures taken by a church against a member to see whether the church has complied with its own law. The question of what law is to govern a church is too intimately connected with religious dogmas and tenets of faith to permit substitution of court-fashioned standards even where the law of the church does not satisfy our secular notions of justice and fairness. But scrutiny of church proceedings to test their adherence to the church-given law, where valuable rights demand judicial protection, in no way violates religious freedom. Our Constitution does not require discrinnination against associations or individuals $\mathrm{m}$ the protection of their rights simply because those rights are connected with the exercise of religion. ${ }^{08}$ Yet this would be the result if courts were to give full protection to membership in other important groups but deny it here.

In this context there should be no room for any special rule by which the decisions of church judicatories are made conclusive and binding on civil courts. If a disciplinary action of an ecclesiastical body was arrived at in substantial compliance with church law, nothing remains for court review. Where the ecclesiastical law was violated, courts should intervene.

In cases involving disputes over property rights following schism or division in a church, the rule of Watson v. Jones to the effect that, absent an express trust providing otherwise, the property should follow the church government has much to recommend it. It avoids difficulties which would invariably arise where the courts must decide fine points of dogma and doctrime. However, a qualification of the rule for cases of complete subversion of fundamental principles of faith should always be insisted on, should such extreme situations arise. Such rule would leave our churches free to adjust to changing social conditions and respond fully to the demands of our times.

H. Helmut Loring*

98 See Everson v. Board of Education, 330 U.S. 1, 17-18 (1947).

*Member, Second-Year Class. 